\title{
A proposal for a standardized system of reporting human lymph node morphology in relation to immunological function ${ }^{1}$
}

\author{
H. COTTIER, J. TURK, AND L. SOBIN ${ }^{2}$
}

From the Department of Pathology, University of Berne, Switzerland, the Department of Pathology, Royal College of Surgeons, London, and the World Health Organization, Geneva

SYNOPSIS This memorandum proposes a standardized system of reporting the histology of human lymph nodes based on commonly used simple staining techniques. The purpose is to provide a uniform, internationally acceptable system by which the histological structure of lymph nodes can be correlated with other parameters of immunological status. The proposed protocols are intended to provide information that is not available in conventional written reports that use such terms as 'hyperplasia' or 'nonspecific lymphadenitis'.

The increasing use of immunological tests in clinical medicine has demonstrated a need for standardized reporting of the appearance of lymph node sections. Although there have been many advances in the knowledge of lymph node structure in the past 10 years as a result of correlation between lymph node changes and immunological function, these have not been reflected in the reports generally issued from histopathology laboratories. Such changes are now well recognized by immunologists but have not yet been adopted by histopathologists, since until now emphasis has been given almost exclusively to major pathological lesions rather than to changes associated with variations in the immune response. The present proposals have been prepared in the hope that pathologists will also comment in their reports on structural variations associated with immunological function. This could add a further dimension to the physician's analysis of the immunological status of the patient analogous to information on the endocrine state as determined by endometrial biopsies. Since the lymph node is one of the tissues most frequently examined by histopathologists, a considerable amount of information is currently being lost because of the lack of a consistent system

\footnotetext{
${ }^{1}$ Reprinted in slightly modified form, and with the addition of a bibliography, from Bulletin of the World Health Organization (1972), 47, 375-406.
}

'Requests for reprints should be addressed to Dr L. Sobin, WHO, 1211 Geneva, 27 Switzerland. of reporting. Correlation between lymph node morphology and other parameters of immunological response, associated with humoral antibody production and cell-mediated immunity, could assist the physician in his final assessment and treatment of the patient. This approach may be of special value in the management of patients with disorders such as neoplastic and infectious diseases.

In the present proposals care has been taken to use terms that are descriptive rather than those based on as yet debatable functional interpretations. Thus the term 'paracortical area' has been used in preference to 'thymus-dependent area' and the term 'large lymphoid cell' in preference to 'immunoblast', 'plasmablast', etc.

\section{Recommendations for Handling and Processing of the Tissue}

Unusual care should be exerted during excision of the lymph node. It is important that the node itself should not be handled with forceps as compression of the tissue during the procedure can result in distortion and prolonged manipulation during surgery can produce acute inflammatory changes. Forceps should be applied only to the surrounding tissue and not to the node. It is strongly recommended that the whole node should be removed rather than fragments of the tissue.

Once removed the node should be cut transversely through its short axis in order to permit 
penetration of the fixative. For a comparable assessment of immunological function it is necessary to examine a transverse section cut along the short axis from the middle portion of the node; this will contain representative areas of the cortex and the medulla.

It is understood that as a routine procedure it may be difficult to use fixatives other than neutral formalin. However, Carnoy's solution is better for the assessment of cellular morphology and is especially useful for subsequent staining with methyl green and pyronin. Although for most purposes haematoxylin-eosin staining is adequate for the examination of the tissue, Giemsa stain or methyl green and pyronin allow very rapid assessment at low-power magnification of the immunologically important cells and structures such as plasma cells and germinal centres.

\section{Recommended Nomenclature for Cell Types in the Lymph Nodes as Seen in Histological Sections}

Ideally, the nomenclature of tissue structures and cells of the lymphoid and plasma cell systems should be based on functional as well as morphological criteria. Although one may say definitely that a mature or immature plasma cell is producing immunoglobulin, one cannot ascribe a function to a given large lymphoid cell or a small lymphocyte purely on morphological appearance. For example, small lymphocytes morphologically identical in tissue sections can be the precursors of plasma cells involved in immunoglobulin synthesis or of the effector cells of cell-mediated immunity. The latter also have the morphological appearance of small lymphocytes. Similarly, it may be difficult to distinguish the large proliferating precursor cells of elements involved in cell-mediated immunity from those involved in immunoglobulin synthesis. Even the precursors of other blood cell lines may resemble large lymphoid cells or small lymphocytes.

Terms such as immunoblast, plasmablast, or haemocytoblast indicate a function that cannot be directly determined from the histological examination of lymphoid tissue alone. The use of these terms is often based on circumstantial evidence and they should be applied only to describe large lymphoid cells in certain controlled immunological situations. For practical reasons, the following nomenclature has been based essentially on the morphological and staining characteristics of cells that are easily recognizable with the aid of simple staining methods and the light microscope. In this way, it should be possible to obtain agreement between pathologists and immunologists on their microscopic findings. The sizes of cells are subject to change as a result of fixation, dehydration, and embedding and an absolute assessment of size is omitted from ? the following description.

Recent developments in cell kinetics have shown that the non-proliferating precursors of all immunologically active cells have the morphological appearance of small lymphocytes. These cells when proliferating and differentiating acquire a common appearance and are referred to here as 'large के lymphoid cells'. During the cell-mediated immune $\overrightarrow{0}$ response these cells will divide into elements that are usually morphologically indistinguishable in tissue sections from the precursor small lymphocyte. Similar cells when proliferating and differentiating ? into plasma cells start off with the same appearance $\widetilde{N}$ and, therefore, should also be called 'large lymphoid on cells'. It is recognized that in tissue sections there are cells that appear identical under the light microscope with small lymphocytes but examination under the electron microscope and the use of immunohistological techniques indicate that they are involved in immunoglobulin synthesis. However, they cannot be recognized as such without the use of these methods.

LARGE LYMPHOID CELLS (figs $1,3,14$ )

These cells have large vesicular nuclei with prominent nucleoli and moderate amounts of basophilic and pyroninophilic cytoplasm. They are frequently seen in mitosis. Cells with these characteristics occur during the proliferation of lymphocytes during a cell-mediated immune response as well as in relation to plasma cell proliferation and in germinal centres in humoral antibody responses, when they may contain immunoglobulin.

MEDIUM-SIZED LYMPHOCYTES (figs 1, 3)

There is a range of nuclear and cytoplasmic size between large lymphoid cells and small lymphocytes. This may reflect transition between a proliferating and resting state as well as some degree of functional differentiation. The term 'medium-sized lymphocyte' is used to describe cells with any appearance in between that of large lymphoid cells and small lymphocytes.

SMALL LYMPHOCYTES (figs $2,3,4$ )

These are defined according to conventional nomenclature.

MATURE PLASMA CELLS (fig 4)

This term is restricted to cells with a typical eccentric cart-wheel nucleus of similar size to that of a small lymphocyte, abundant basophilic and pyroninophilic cytoplasm, and a pale paranuclear area. 


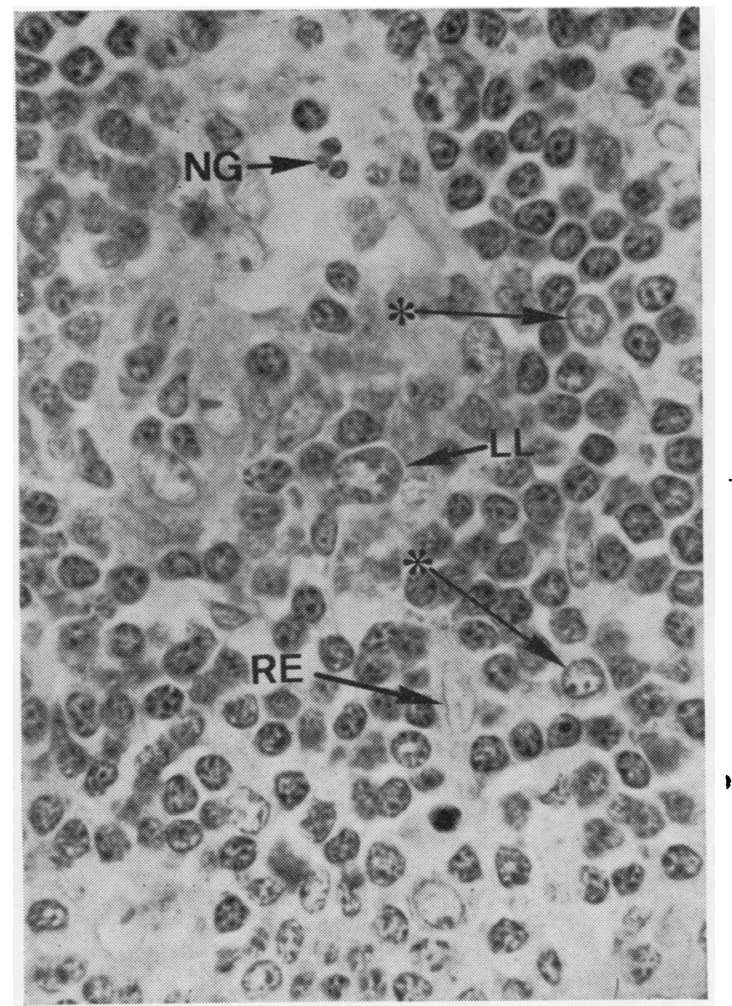

Fig 1

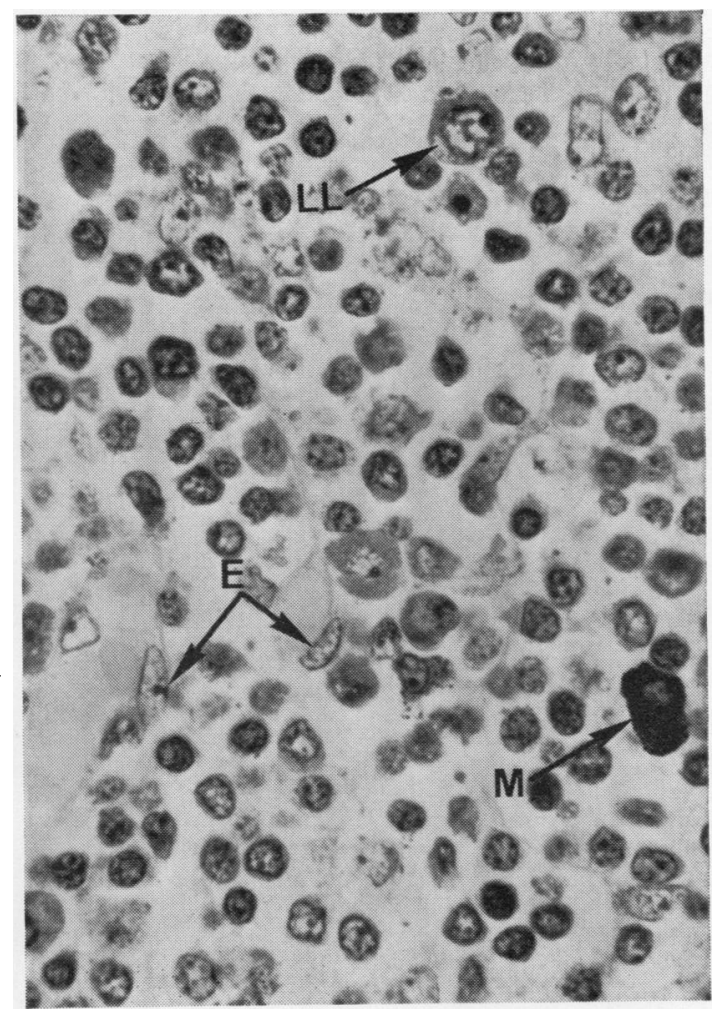

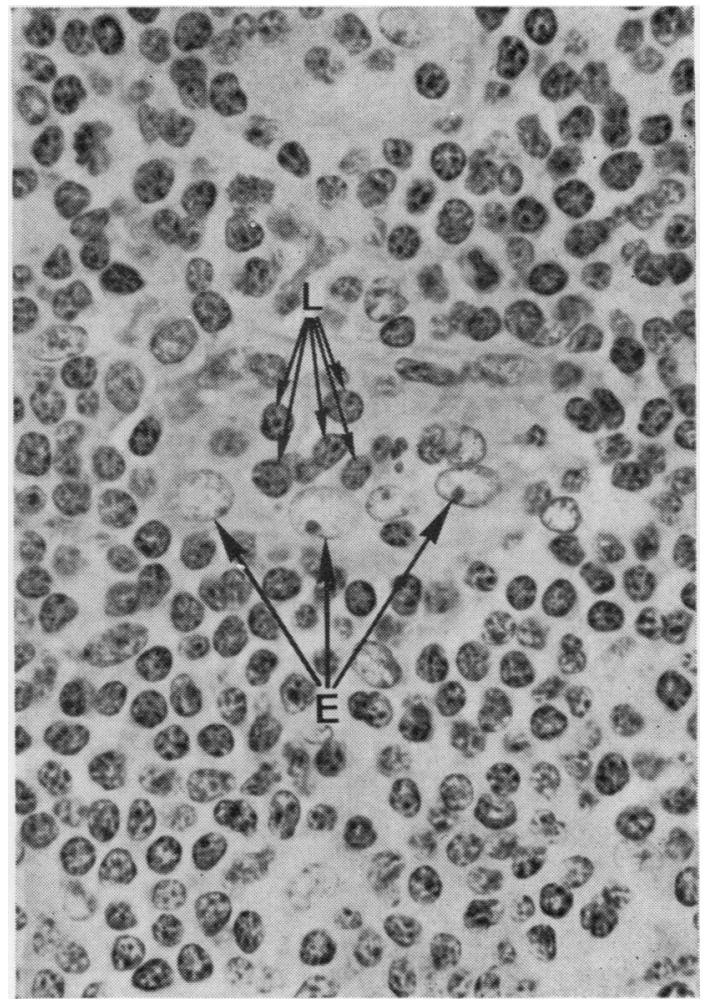

Fig 2

Fig 1 Corticomedullary junction of a lymph node. $L L$, large lymphoid cell; $R E$, reticulum cell or endothelial cell (endothelial cells may resemble reticulum cells in tangential sections); $N G$, neutrophilic granulocyte. Note that in sections only a few micrometres in thickness, and without special staining, it is often difficult to distinguish between medium-sized lymphocytes and a cross-sectioned reticulum cell (examples are marked with an asterisk) ( $\times 375)$.

Fig 2 Predominantly small lymphocytes surrounding a postcapillary venule in the paracortical area of a lymph node. $E$, large endothelial cells of the postcapillary venule; $L$, small lymphocytes within the lumen and the wall of the postcapillary venule $(\times 375)$.

Fig 3 Medullary cord of a lymph node with small and medium-sized lymphocytes. LL, large lymphoid cell; $E$, endothelial cells of small blood vessels; $M$, mast cell. (Giemsa, methacrylate, $\times 375$ ).

Figs 1-4 illustrate the simplified cell type nomenclature in histological sections. For histiocytes-macrophages see figs 5-7, 13 and 14.

All the figures except figs 3 and 4 are from paraffinembedded preparations stained with haematoxylin and eosin. 


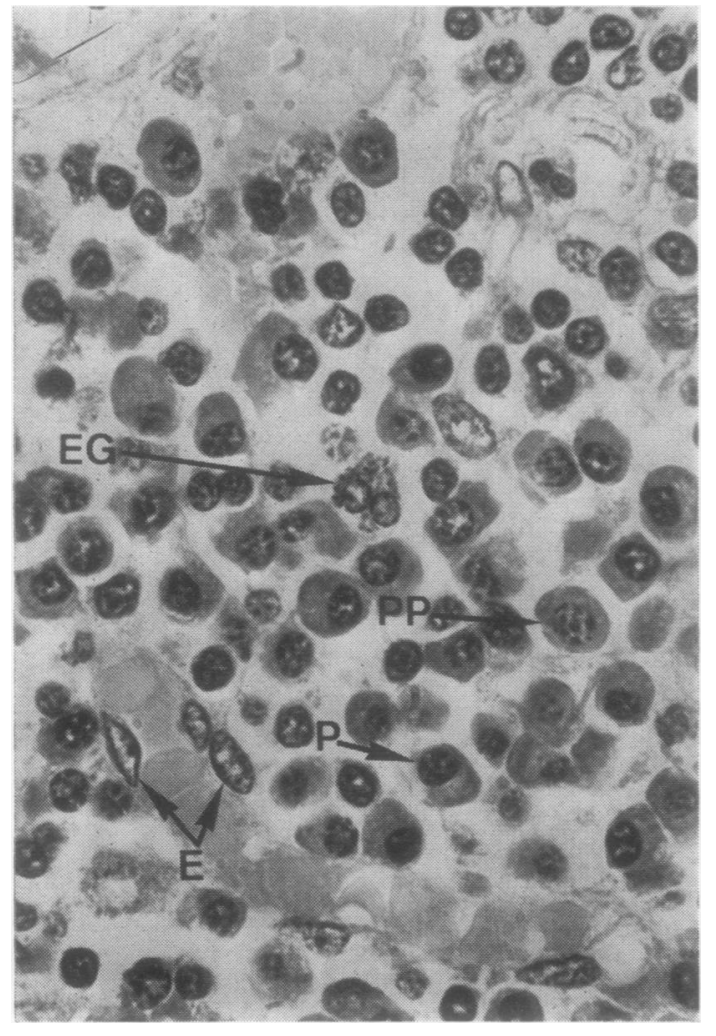

Fig 4 Medullary cord of a lymph node containing mainly plasma cells and small lymphocytes. PP, plasma cell that may be regarded as being in a state of more active antibody production than the old, mature plasma cell $(P)$, which has a small, dense nucleus. Aspects of immature plasma cells range between that of a large lymphoid cell and the one shown here as PP. One may also notice in this photograph cells intermediate between lymphocytes and plasma cells. E, endothelial cells of a small blood vessel; EG, eosinophilic granulocyte. (Giemsa, methacrylate, $\times 375$ ).

imMATURE PlaSMa CELls (fig 4)

This term is used to indicate a series of cellular patterns intermediate between the large lymphoid cell and the mature plasma cell. These cells can be seen in mitosis but they differ from the large lymphoid cell in that the nucleus is generally eccentric in the cytoplasm, which is usually more abundant than that seen in the large lymphoid cells. The immature plasma cell can be demonstrated to contain immunoglobulin in the same way as mature plasma cells.
HISTIOCYTE-MACR OPHAGE (figs 5-7, 13, 14)

Histiocytes are large cells that usually have abundant cytoplasm that is neither strongly basophilic nor pyroninophilic. These characteristics distinguish them from large lymphoid cells. Histiocytes have medium-sized, often kidney-shaped, pale nuclei generally with solitary prominent nucleoli. The term 'macrophage' should be used only if there is evidence of phagocytosis, e.g., for the tingible body- is macrophages in the germinal centres or those in the $\overrightarrow{0}$ medulla that contain pigment, carbon particles, or $\overrightarrow{\vec{H}}$ other material. In the absence of such evidence the term 'histiocyte' should be used for these cells. Histiocytes may take on an epithelioid appearance when in close proximity to or when participating in o certain types of cell-mediated immune reaction. These cells may also be phagocytic for bacteria (e.g. $\underset{\forall}{\forall}$ in leprosy). Histiocytes may enter the lymph nodes through the afferent lymphatic vessels and infiltrate the paracortical areas, e.g., when the lymph node $z$ drains an area of chronically inflamed skin, as in dermatopathic lymphadenopathy or in certain $\vec{\theta}$ infectious diseases. Histiocytes may also accumulate in the sinuses, particularly of the medulla, and this is referred to as sinus histiocytosis. Histiocytes are derived from circulating monocytes or from preexisting cells of this type.

RETICULUM CELLS (fig 1)

These cells form reticulin fibres and are part of the basic supporting structure of the lymph node. When the lymphoid tissue is depleted or hypoplastic these cells remain to form a background structure, together with endothelial cells of the lymphatic channels. They may proliferate in certain situations, eg, during infection or following lymphocyte depletion. Reticulum cells and histiocytes may resemble each other superficially, but the former usually have a spindle cell appearance. Further differentiation can be obtained by the use of special techniques, such as the demonstration of enzymatic activities $^{1}$. There is no evidence that reticulum cells are precursors of immunologically active cells.

\section{LYMPHATIC ENDOTHELIAL CELLS}

These cells line the lymphatic sinuses and vessels. They are in close contact with reticulum cells and have some phagocytic properties. They are also known as littoral cells.

OTHER CELLS

The other types of cell found in a lymph node are defined in the conventional manner.

${ }^{1}$ Acid phosphatase activity is characteristic for histiocyte-macrophages but not for reticulum cells. 


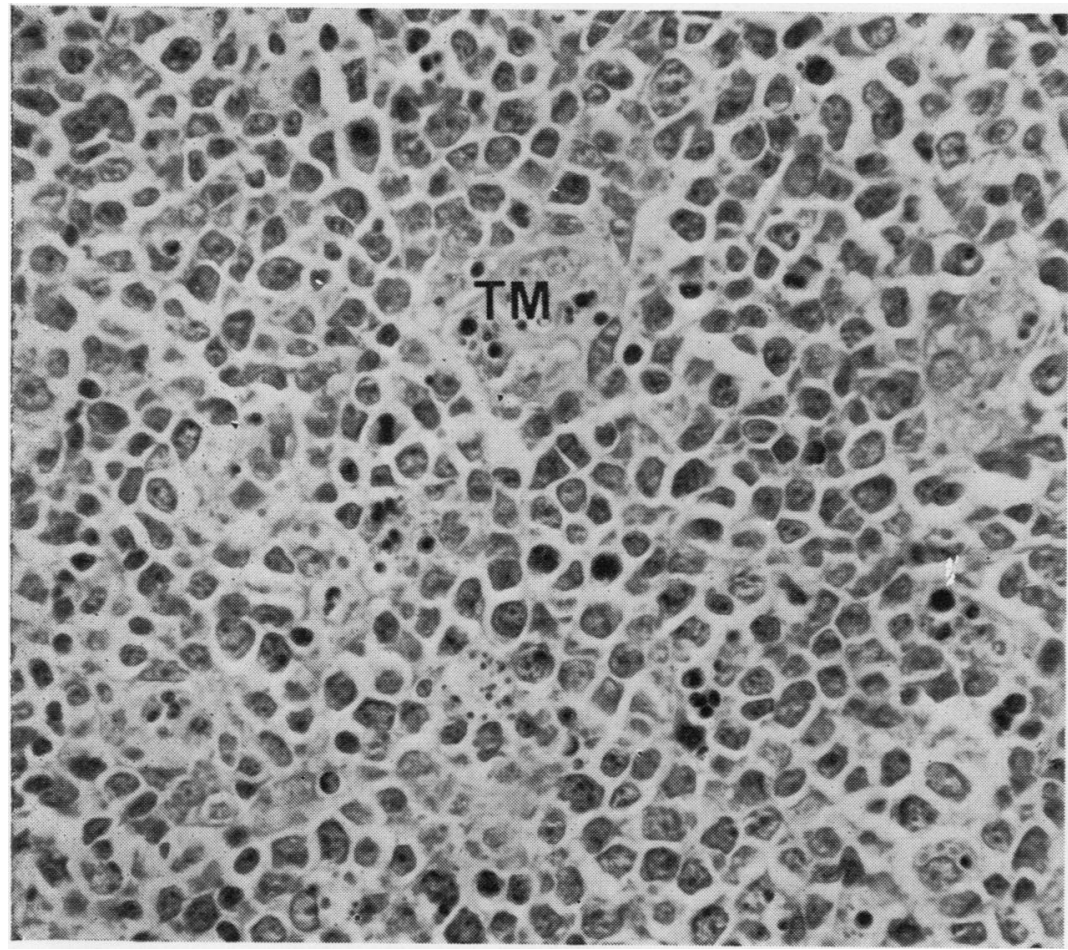

Fig 5 Basal area of a large germinal centre with many tingible body macrophages $(T M)$ containing cellular $\stackrel{0}{5}$ debris. A rather high death rate is typical for heavily proliferating large lymphoid cells in germinal centres $(\times 320)$.

Fig 6 Paracortical area containing several postcapillary venules $(P C V)$, predominantly small lymphocytes, scattered macrophages, and occasional in large lymphoid cells. The relative $\vec{\circ}$ number of lymphocytes within the lumen and the wall of postcapillary venules $\overrightarrow{\vec{\omega}}$ gives an estimate of the magnitude of lymphocyte recirculation $(\times 200)$.

Fig 7 Medulla of a lymph node showing medullary cords (MC) and medullary lymphatic sinuses (LS) containing lymphocytes, histiocytemacrophages (HM), and some large lymphoid cells. An increase in the relative number of intrasinusoidal large $\overline{ }$ lymphoid cells is noted rather early in an immune response $(\times 206)$.

Fig 5

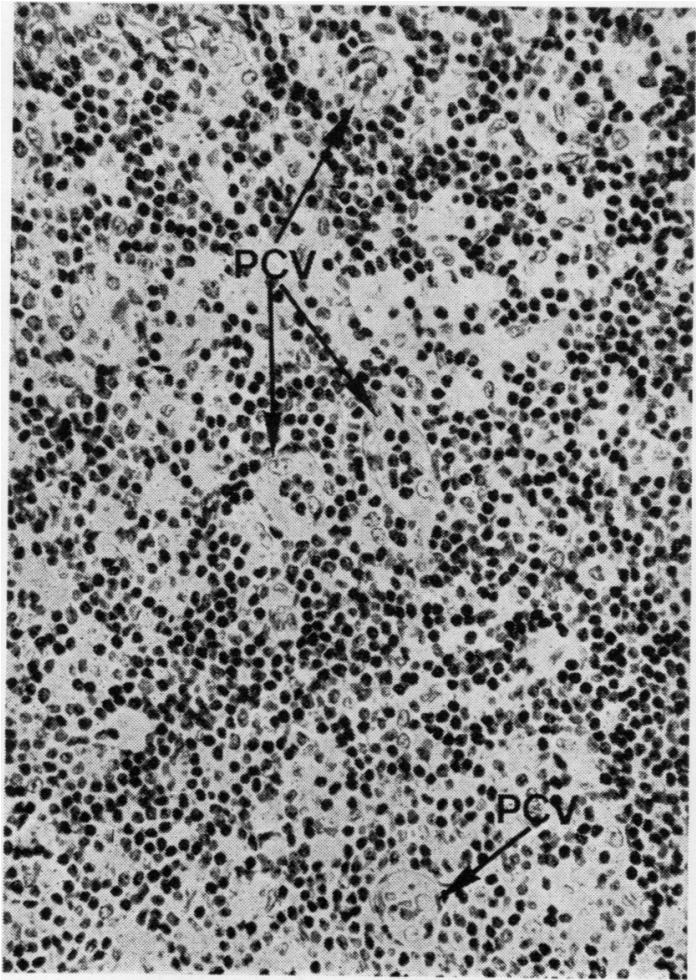

Fig 6

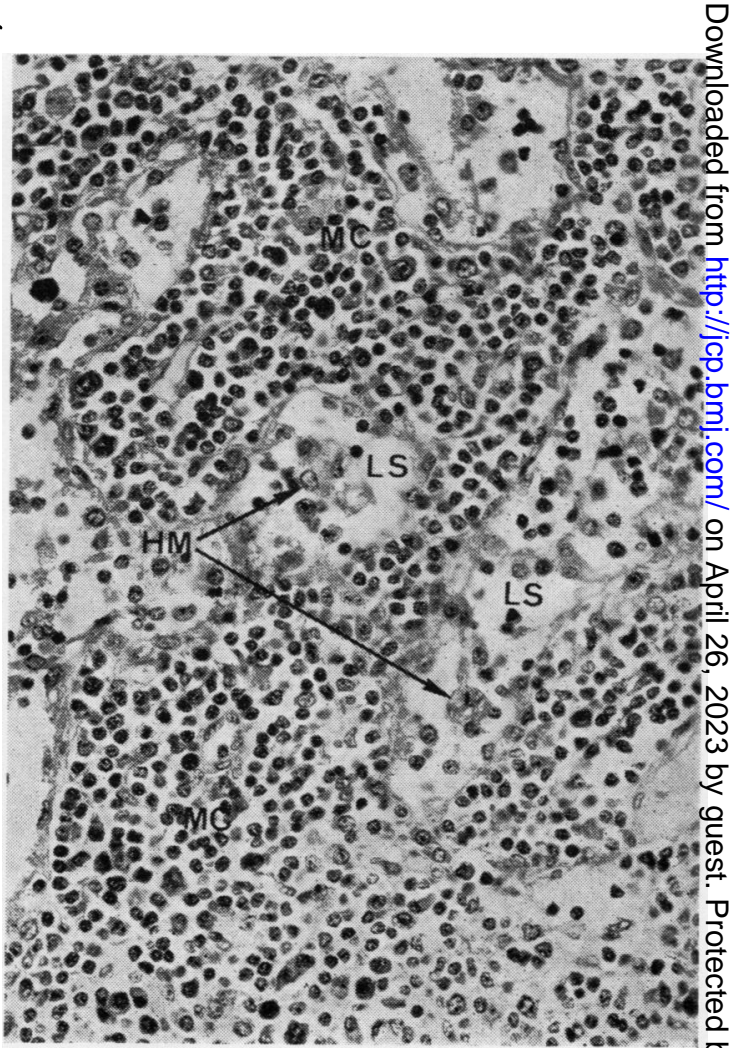

Fig 7 


\section{Fig 8}

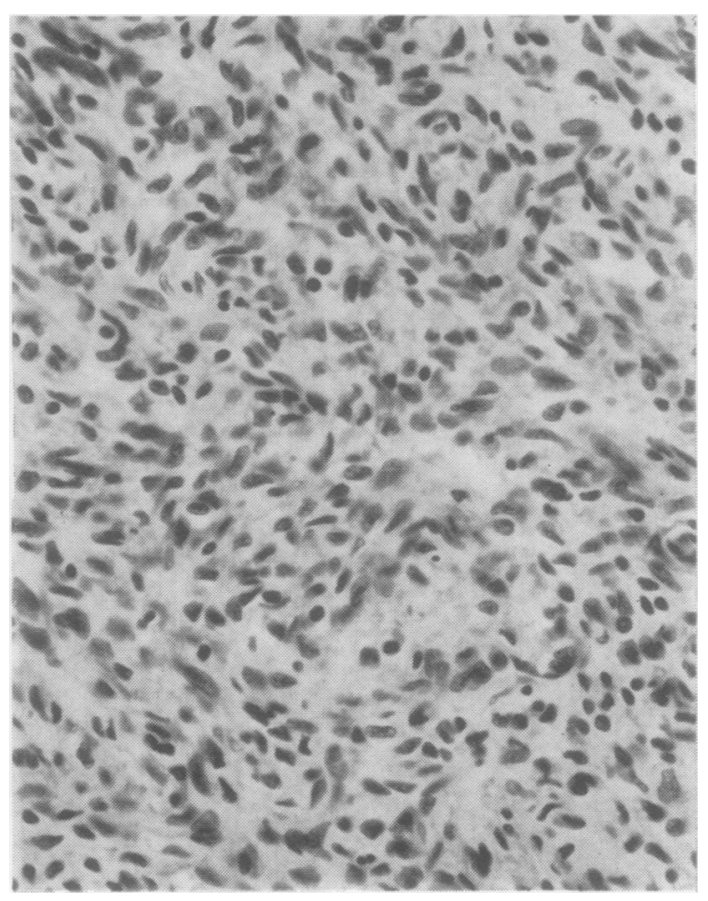

Fig 9

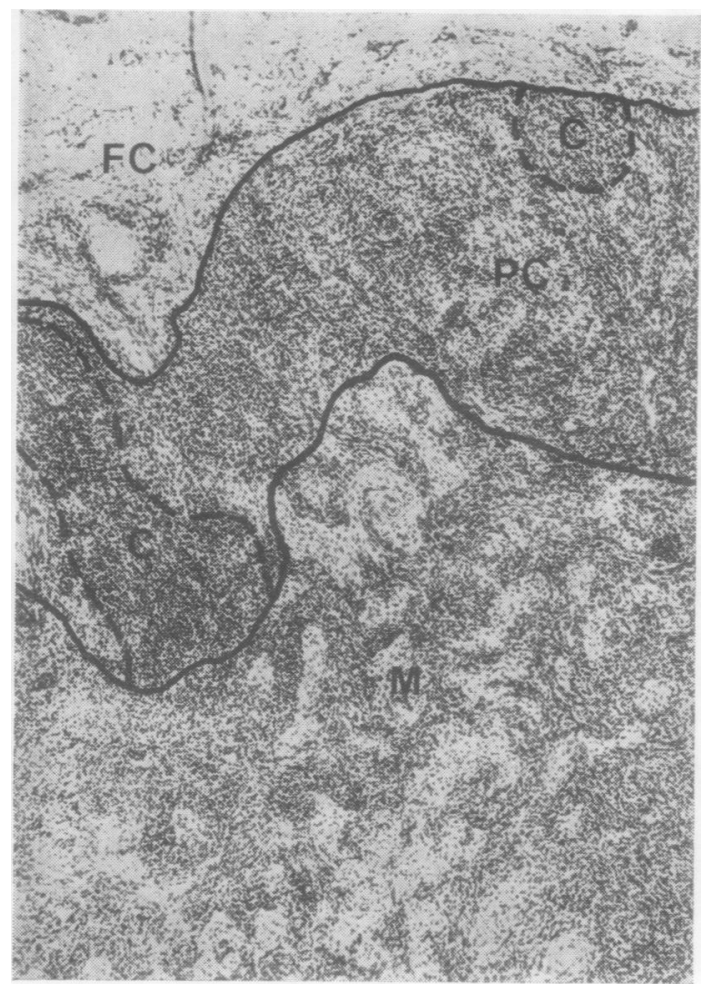

Fig 8 Lymph node in Swiss-type agammaglobulinaemia with diffusely altered architecture $(+++)$ : lymphocyte content in all areas almost nil (- -$)$; lymphocytic follicles, germinal centres, and plasma cells absent (- - -); sinus width greatly reduced (- - ). The lymph node consists mainly of densely arranged reticulum cells and fibrocytes $(\times 75)$.

Fig 9 The same lymph node as shown in fig 8 at higher magnification $(\times 300)$.

Fig 10 Lymph node in agammaglobulinaemia (probably Bruton's type): architecture slightly altered $(+)$, size of cortical area reduced (- - ), lymphocyte content in all areas below normal (-), absence of germinal centres $(---)$ and plasma cells $(---)$. FC, fibrous capsule; $C$, cortical area; $P C$, paracortical area; $M$, medulla ( $\times 50)$.

Figs 8-13 illustrate deviations from normal lymph node morphology. The grading symbols refer to those used in the protocols in Appendix I and Appendix II. 


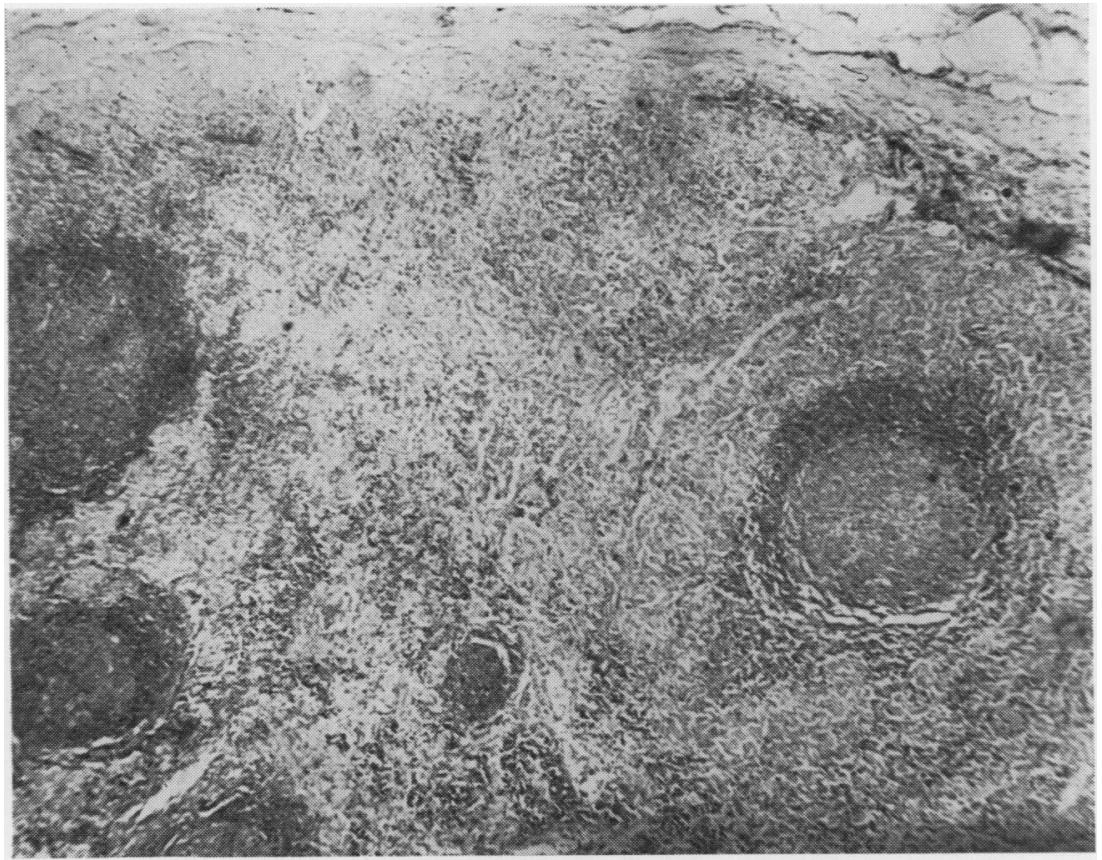

Fig 11 Lymph node in lepromatous leprosy: germinal centres and their lymphocytic cuff well developed $(+)$; however, the paracortical area is almost devoid of lymphocytes (- - ), has increased in size $(++)$, and reaches the lymph node capsule $(\times 30)$.

Fig 11

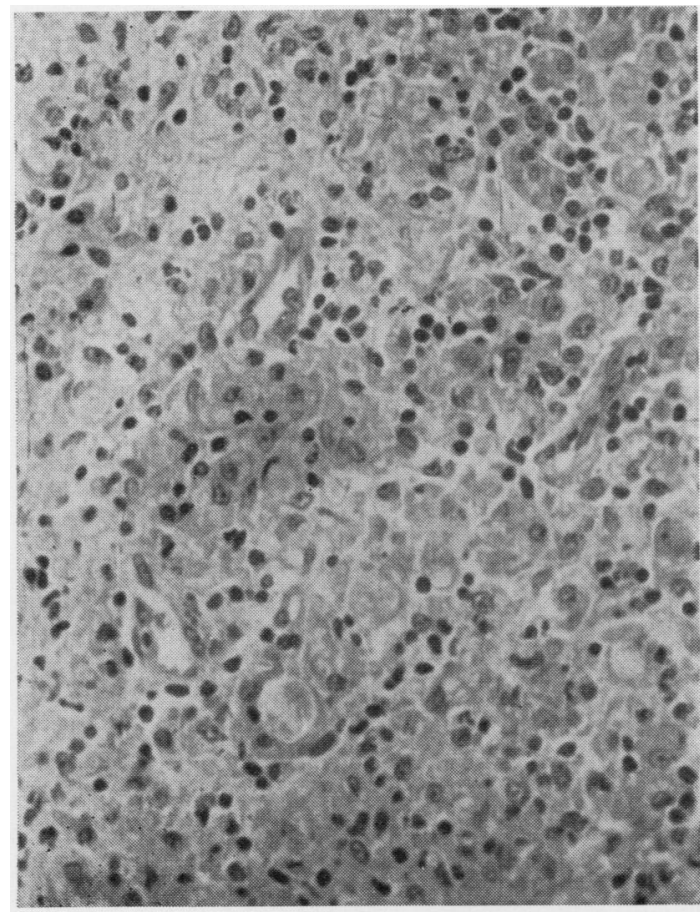

Fig 12

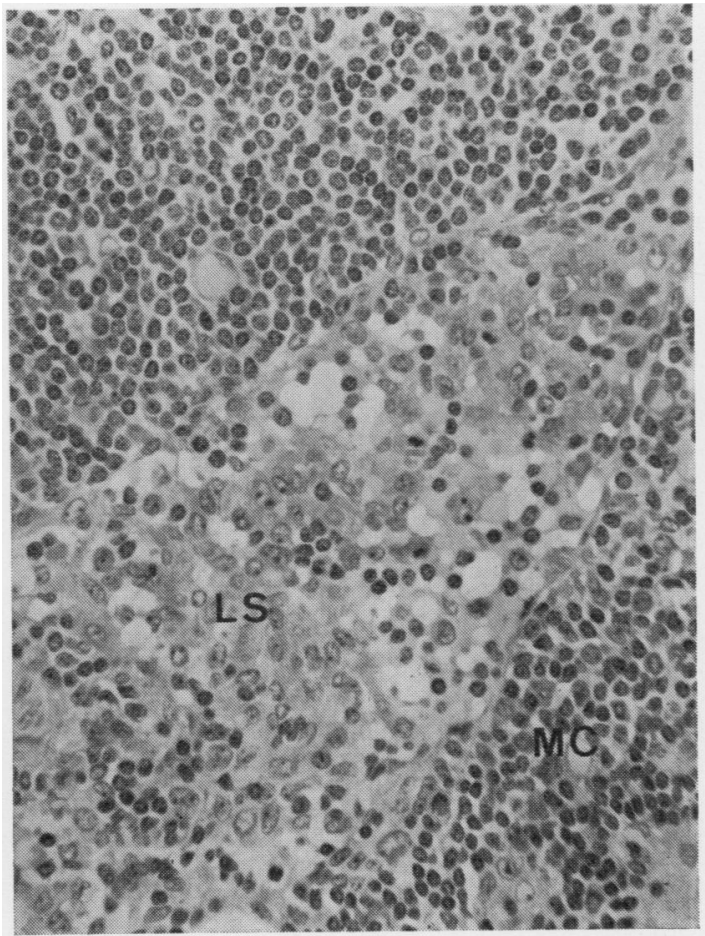

Fig 13

Fig 12 High-power view of paracortical area in Figure 11. This is heavily infiltrated $(+++)$ by foamy histiocytemacrophages (lepra cells), which with Ziehl-Neelsen staining show large numbers of M. leprae. Very few lymphocytes remain $(--)(\times 200)$.

Fig 13 Lymphatic sinus containing (LS) numerous large histiocyte-macrophages $(++)$. Changes such as this are referred to as sinus histiocytosis $(\times 200)$. MC refers to medullary cord. 


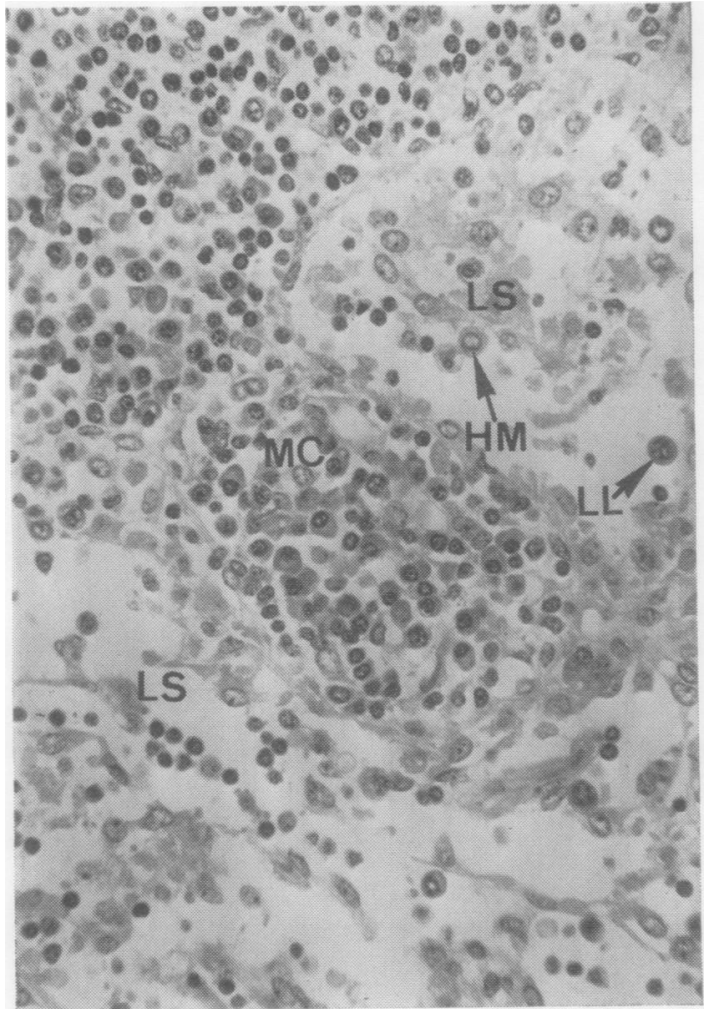

Fig 14 Medulla of a lymph node with medullary cords (MC) containing increased numbers of plasma cells $(++)$. The lymphatic sinuses $(L S)$ are of usual width $(N)$ and show a normal content $(N)$ in histiocyte-macrophages (HM), small lymphocytes, and large lymphoid cells $(L L)$ $(\times 200)$.

\section{A Topographical Description of Lymph Node Sections (figs 5-22)}

The following terms are recommended for the description of discrete areas of lymph nodes as shown in figure 15.

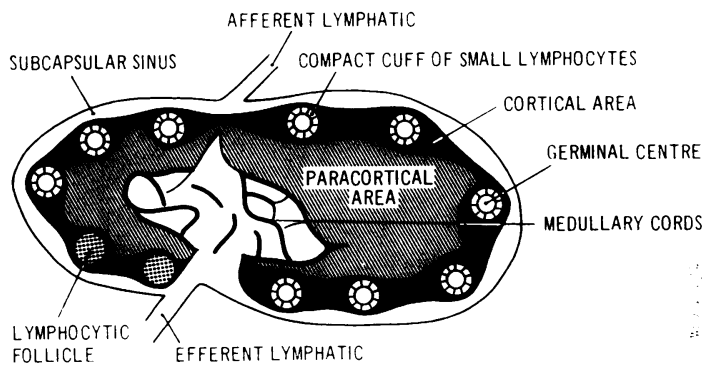

Fig. 15 Diagram of immunologically active lymph node
1 CORTICAL AREA (OUTER CORTEX) (figs 16-19) This usually lies under the subcapsular sinus and consists of a dense population of predominantly small lymphocytes. There is usually a scarcity of large lymphoid cells, plasma cells, and blood vessels, especially postcapillary venules. This area is the site of the lymphocytic follicles and germinal centres. Sometimes such cortical tissue may be absent from the subcapsular region or may lie deeper in the node, even in the medullary cords.

2 LYMPHOCYTIC FOLLICLE (figs 16-21)

This structure is a spherical or ovoid nodule containing mainly a dense collection of small or medium-sized lymphocytes.

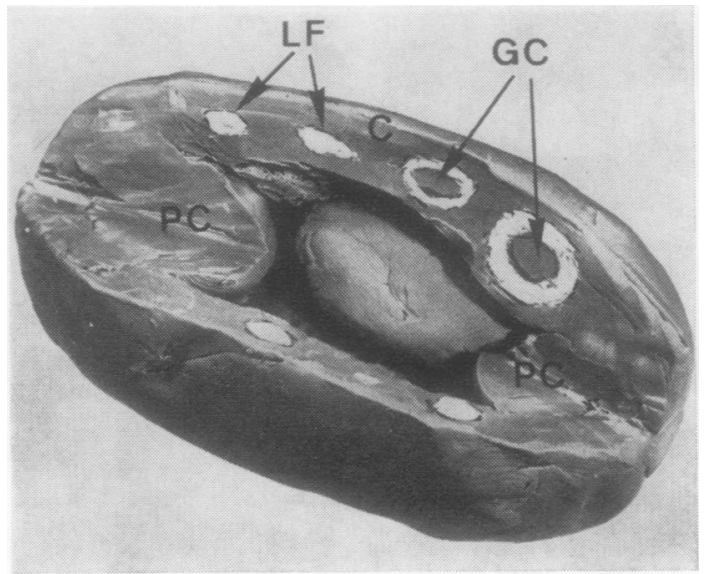

Fig 16 Schematic three-dimensional model of lymph node topography (J. Oort) showing the cortical area $(C)$, the paracortical area $(P C)$, lymphocytic follicles $(L F)$, and germinal centres $(G C)$. The medulla is the central space shown in this model.

3 Germinal CENTRE (figs 16-19, 22)

This is a spherical or oval structure surrounded by a dense cuff of mainly small lymphocytes. It consists of a basal area that usually contains densely packed large lymphoid cells, many of which are in mitosis, and a considerable number of tingible body-macrophages (containing nuclear debris) (fig 5). There is a lighter staining zone often directed towards the capsule with more loosely arranged large lymphoid cells and medium-sized lymphocytes, and often a few immature plasma cells. The supporting structure of the germinal centre consists of a loose network of dendritic reticulum cells (often erroneously referred to as dendritic macrophages). These cells cannot 


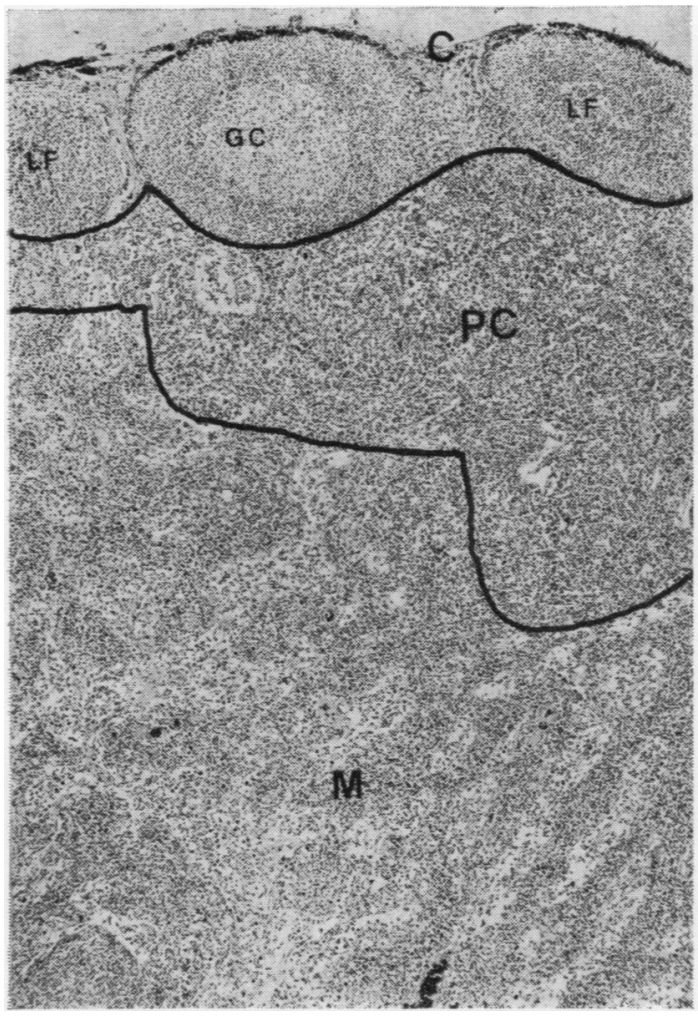

Fig 17

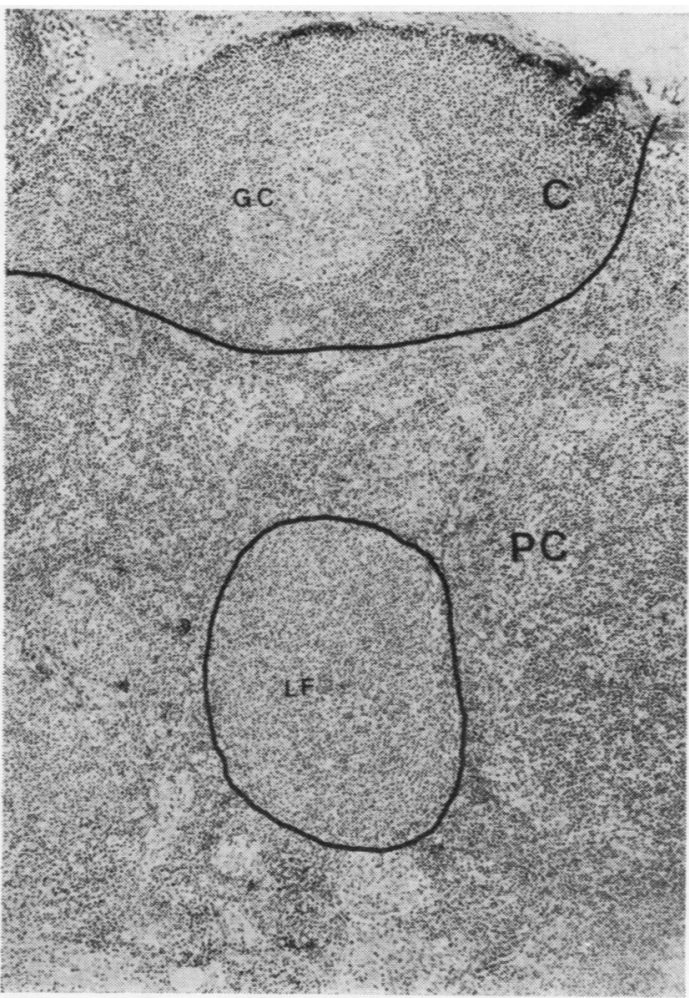

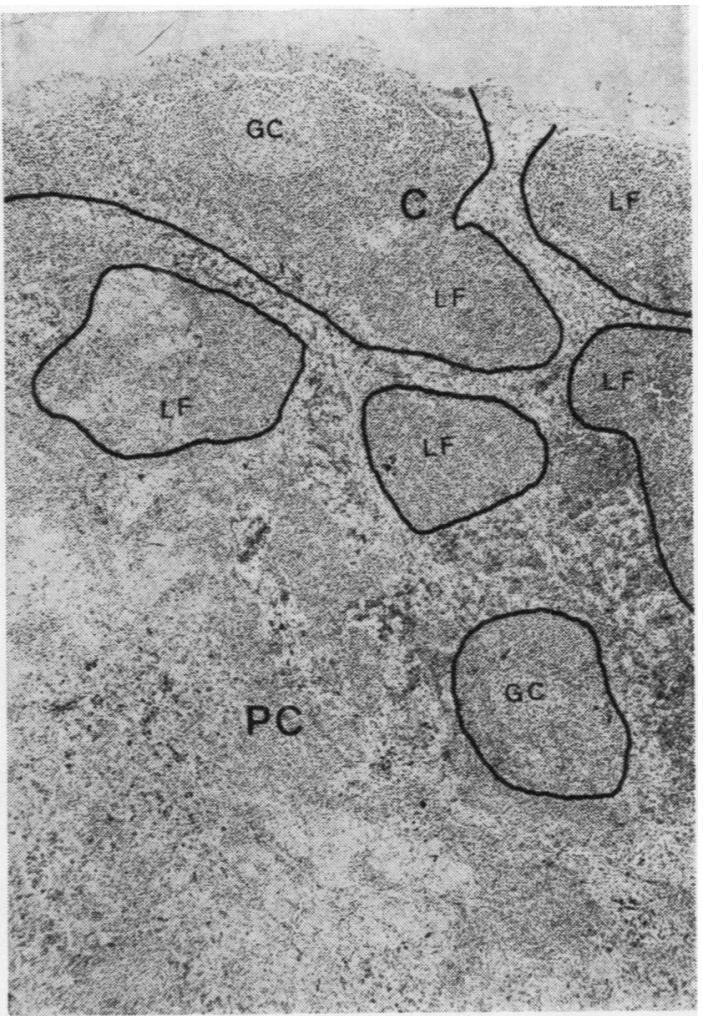

Fig 18

Fig 17 Section of a lymph node with the usual arrangement of cortical area $(C)$, paracortical area $(P C)$, and medulla $(M) . L F$, lymphocytic follicles; GC, germinal centre. Recirculating lymphocytes are located preferentially in the paracortical zone $(\times 32)$.

Fig 18 In this section, lymphocytic follicles $(L F)$ and germinal centres $(G C)$ of the cortical area $(C)$ are in part separated from each other by interdigitating paracortical tissue $(P C)(\times 32)$.

Fig 19 This photograph shows the typical cortical area (C) with a germinal centre (GC) and the paracortical area $(P C)$. There is, however, a lymphocytic follicle $(L F)$ located near the corticomedullary junction $(\times 46)$.

Figs 18-20 illustrate the fact that in man cortical, paracortical, and medullary tissues are not always clearly separated into distinct zones. 


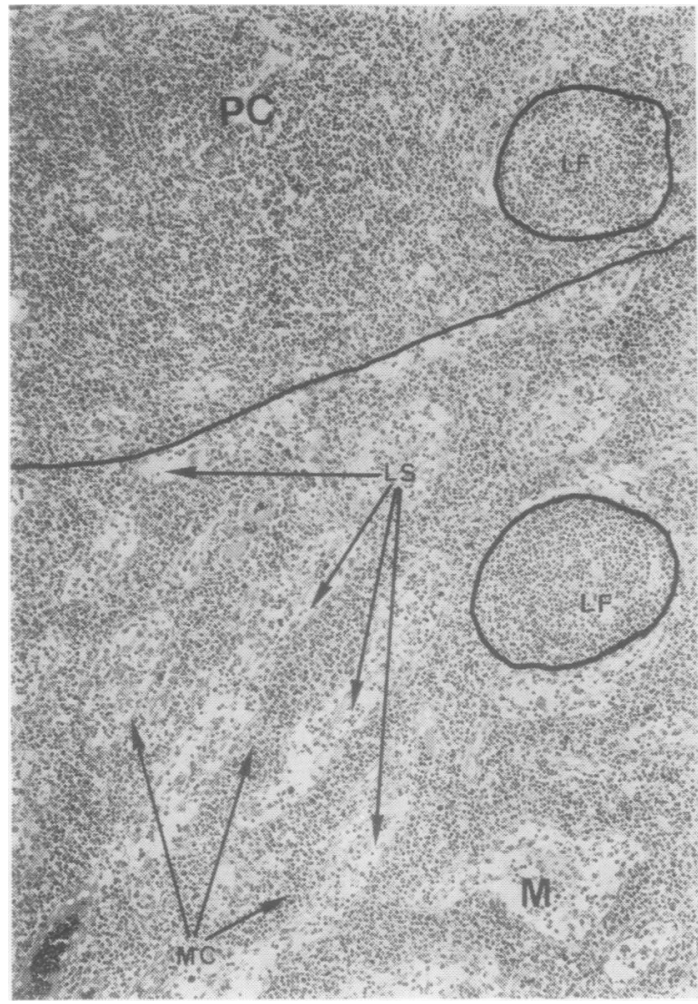

Fig 20

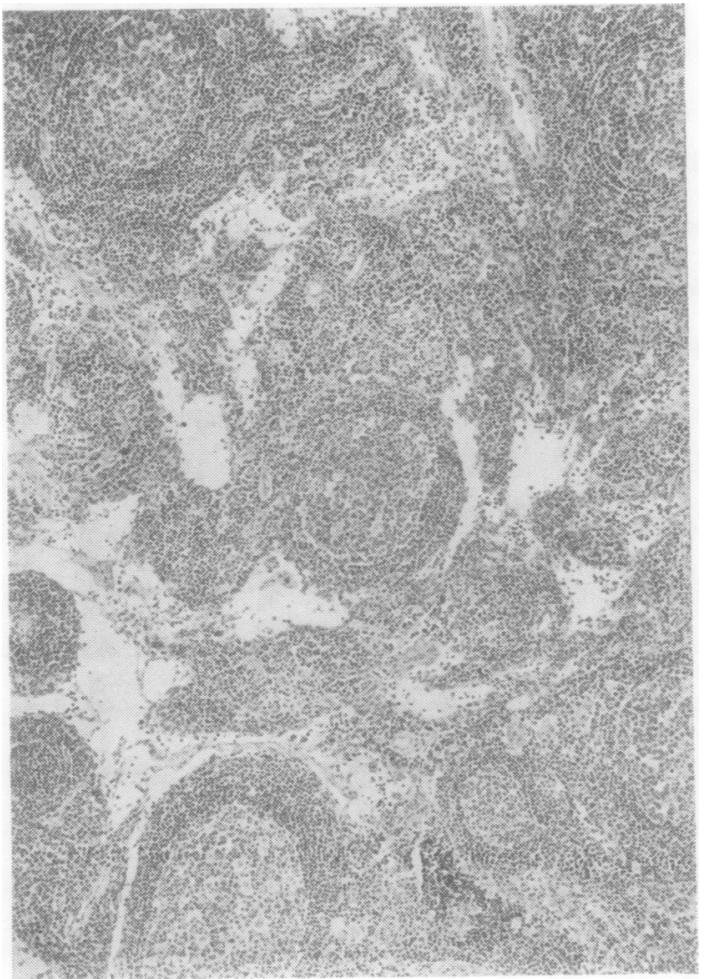

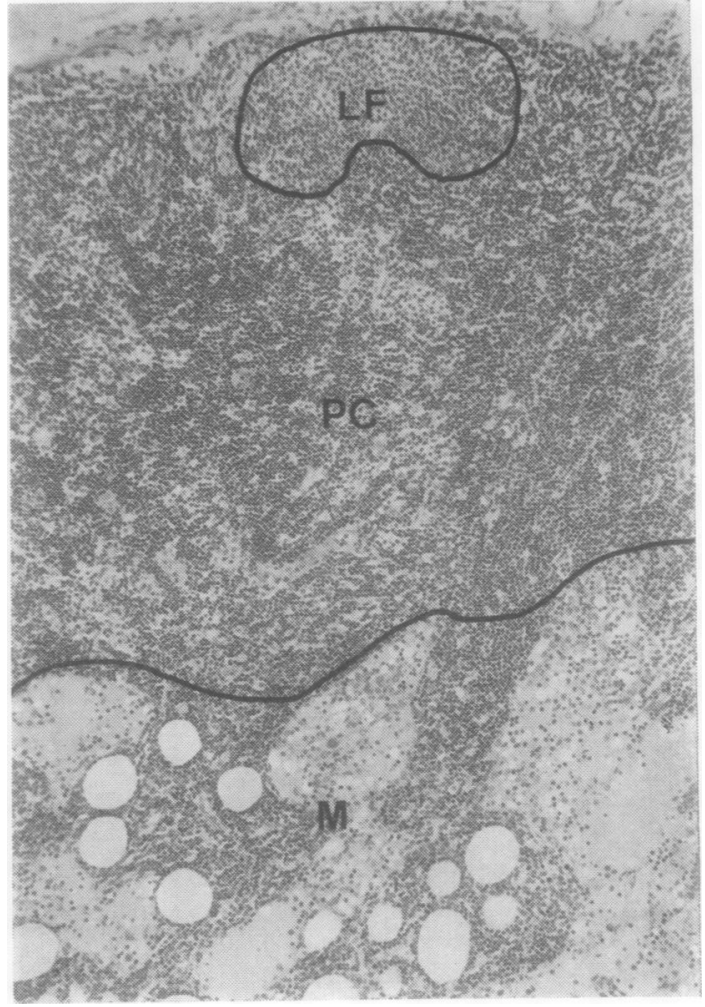

Fig 21

Fig 20 This depicts lymph node tissue near the corticomedullary junction. Lymphocytic follicles $(L F)$ lie within the paracortical area $(P C)$ as well as within the medulla (M). LS, lymphatic sinuses; MC, medullary cords $(\times 46)$.

Fig 21 Section of a lymph node with a fairly large paracortical area $(P C)$ and a small remnant of cortical tissue in the form of a lymphocytic follicle ( $L F)$

consisting predominantly of small lymphocytes. Expansion of the paracortical area is associated with an immune response of the cell-mediated type. $M$, medulla. The roundish holes are the result of a recent lymphography $(\times 50)$.

Fig 22 In this field, germinal centres surrounded by a dense cuff of mainly small lymphocytes are located within or near medullary cords of the lymph node. This is not a usual finding; it occurs in hyperimmune antibody responses $(\times 50)$. 
readily be recognized without special staining techniques. Following intense and persistent antigenic stimulation, germinal centres may extend deep into the lymph node, even into the medullary cords. Very large germinal centres are a sign of the acute and subacute stages of certain infectious diseases, such as syphilis, certain viral infections, and toxoplasmosis. In the late stages of germinal centre development there may be relatively fewer large lymphoid cells. Germinal centres are always associated with humoral antibody production although their exact function, especially their relationship to plasma cell proliferation in the medulla, is not understood. The germinal centre with its lymphocytic cuff has also been called the secondary follicle.

\section{PARACORTICAL AREA (INNER CORTEX) (figs 16-21)}

This usually lies beneath or interdigitates with the cortical area. It may be defined as the loosely arranged lymphoid tissue lying in close relation to the postcapillary venules (figs 2,6 ). It may extend from beneath the capsule down to the corticomedullary junction. It may or may not be separated from the capsule by the cortex and may or may not be broken up by groups of plasma cells in what has been called the interfollicular zone. Wide open lymphatic sinuses are not a feature of this area. The paracortical area may swell up during the early stages of a cell-mediated immune response when the flow of lymphocytes may be blocked as a result of the lymphatic sinuses in the medulla being choked with lymphocytes and/or of the narrowing of the lymphatic vessels. Most lymphocytes present in the paracortical area enter it through the postcapillary venules. The number of lymphocytes seen within the walls of these specialized vessels can indicate the magnitude of lymphocytic entry. The cuboid endothelial cells of the postcapillary venules are particularly voluminous during an immune response. The paracortical area is the main site of the proliferation of lymphocytes in a cell-mediated immune response and may then contain great numbers of large lymphoid cells, many of which may be in mitosis. As it is the area containing the mobile pool of small lymphocytes it will be depleted by any measures that damage or eliminate circulating lymphocytes, eg, chronic thoracic duct drainage or treatment with antilymphocyte serum. In thymic hypoplasia this zone also contains only small numbers of lymphocytes. The paracortical area may be infiltrated with histiocytes draining down the afferent lymphatics. Epithelioid cell granulomas (eg, in sarcoidosis) may be found especially in the paracortical areas.

\section{MEDULLARY CORDS}

These are the main site of plasma cell proliferation in humoral anibody production. Medullary cords generally contain large lymphoid cells, immature plasma cells, and mature plasma cells in different proportions as well as lymphocytes. The medullary cords may extend, under intense antigenic stimulation, up to the capsule and may ever replace the whole lymph node.

6 LyMPHATIC SinUSES (figs $7,13,14,17,20-22$ ) The first set of lymph nodes draining the periphery receives, via the afferent lymphatics, a considerable number of histiocytes and macrophages and only relatively few lymphocytes. In contrast, the subcapsular sinus of more central lymph nodes contains proportionally more lymphocytes than cells of the histiocyte-macrophage series. Histiocytic reactions in the peripheral tissues will result in these cells draining down the afferent lymphatics, eventually accumulating in the medullary sinuses. This condition is referred to as sinus histiocytosis (fig 13). The type of inflammatory infiltrate in peripheral tissues is often reflected in the content of the lymphatic sinuses as a result of drainage. Large lymphoid cells and immature plasma cells may occasionally be found in the medullary sinuses early on in the development of an immune response. The passage of these cells up the lymphatic chain is a means by which the immune response is conveyed from the peripheral lymph nodes to more central lymphoid tissue.

The above descriptions are based on the twodimensional appearance of tissue sections. However, it should always be borne in mind that the lymph node is a three-dimensional structure. Many of the variations in appearance from those described above may be artefacts resulting from eccentric sectioning of the specimen.

\section{Variations of Lymph Node Structure and Composition}

It is recognized that the composition and size of the different components of lymph nodes may vary in relation to age and also to the site of the body from which they are taken. For example, mesenteric lymph nodes usually have more well developed medullary cords and wider medullary sinuses than peripheral lymph nodes. Germinal centres are more frequent and of larger size in lymph nodes draining areas of continuous antigenic stimulation, such as those in the neck and in the abdomen. Germinal centres are also more frequent in the lymph nodes of young people than in the elderly, but are virtually absent from the newborn. In addition, the previous condition and treatment of the patient has to be 
considered in evaluating lymph node appearance. For example, in lymph nodes from patients who suffered from hypoxia for a period before death it may be seen that the germinal centres are depleted of lymphoid elements and exhibit excessive nuclear fragmentation. The number of cells showing mitotic activity may be reduced if tissue specimens are not fixed immediately.

\section{Proposed Systems for Uniform Reporting on Lymph Node Histology}

The protocol shown in Appendix I provides an abbreviated scheme in which the morphology of the lymph node is considered as it relates to presumed potential immune capacity and/or active immune responses.

The protocol shown in Appendix II is an example of an expanded way in which a pathologist can record the morphological characteristics of the lymph node in a manner that will convey information relating to the immunological status of the patient. This protocol may be considered too complex for the busy surgical pathologist but it is intended to serve as a guide in his daily work and as a basis for reporting on those cases that might be of particular immunological interest. It is intended especially as a format for recording morphological data during studies on special aspects of immunohistology. It should provide data that might be correlated with immunological functions that are not available in the conventional written reports, which use terms such as 'hyperplasia of lymph nodes' and 'nonspecific lymphadenitis' that have little or no immunological meaning.

We thank the pathologists and immunologists who provided valuable criticism and advice.

\section{Bibliography}

Caffrey, R. W., Everett, N. B., and Rieke, W. O. (1966). Radioautographic studies of reticular and blast cells in the hemopoietic tissues of the rat. Anat. Rec., 155, 41.

Cottier, H., Cronkite, E. P., Jansen, C. R., Rai, K., Singer, S., and Sipe, C. R. (1964). Studies on lymphocytes. III. Effects of extracorporeal irradiation of the circulating blood upon the lymphoreticular organs in the calf. Blood, 24, 241.

Cottier, H., Hess, M. W., Roos, B., and Gretillat, P. (1969). Regeneration, Hyperplasie und Onkogenese der lymphoretikulären Organe. In Handbuch der allgemeinen Pathologie, edited by $(\mathrm{H}$. Altmann, F. Büchner, H. Cottier, E. Grundmann, G. Holle, E. Letterer, W. Masshoff, H. Meessen, F. Roulet, G. Seifert, G. Siebert, and A. Studer, Bd. V/I2, p. 498. Springer, Berlin, Heidelberg, and New York).

Cottier, H., Hess, M, W., and Stoner, R. D. (1967). Summary and closing remarks. In Germinal Centers in Immune Responses (edited by $\mathrm{H}$. Cottier, N. Odartchenko, R. Schindler, and C. C. Congdon, p. 460. Springer, Berlin, Heidelberg, and New York

Cottier, H., Odartchenko, N., Keiser, G., Hess, M., and Stoner, R. D. (1964). Incorporation of tritiated nucleosides and amino acids into lymphoid and plasmacytoid cells during secondary responses to tetanus toxoid in mice. Ann. N.Y. Acad. Sci. 113,612 .
Cottier, H., Odartchenko, N., Schindler, R., and Congdon, C. C., Eds. (1967). Germinal Centers in Immune Responses. Springer, Berlin, Heidelberg, and New York.

Davies, A. J. S., Carter, R. L., Leuchars, E., Wallis, V., and Koller, P. C. (1969). The morphology of immune reactions in normal, thymectomized and reconstituted mice. I. The response to sheep erythrocytes. Immunology, 16. 57.

Davies, A. J. S., Carter, R. L., Leuchars, E., and Wallis, V. (1969). The morphology of immune reactions in normal, thymectomized and reconstituted mice. II. The response to oxazolone. Immuno$\log y, 17,111$.

Fiore-Donati, L., and Hanna, M. G., Jr., Eds. (1969). Lymphatic tissue and germinal centers in immune response. Advanc. exp. Med. Biol., 5

Gaafar, S. M., and Turk, J. L. (1970). Granuloma formation in lymph nodes. J. Path., 100, 9.

Good, R. A., and Finstad, J. (1969). Essential relationship between the lymphoid system, immunity and malignancy. Nat. Cancer Inst. Monogr., 31, 41

Gowans, J. L., and Knight, E. J. (1964). The route of recirculation of lymphocytes in the rat. Proc. roy. Soc. B, 159, 257.

Gowans, J. L., and McGregor, D. D. (1965). The immunological activities of lymphocytes. Progr. Allergy, 9. 1.

Hess, M. W., Roos, B., and Cottier, H. (1971). Kinetics of peripheral macrophages: facts and a working hypothesis. Ann. Inst. Pasteur, 120, 367.

Joel, D. D., Hess, M. W., and Cottier, H. (1972). Magnitude and pattern of thymic lymphocyte migration in neonatal mice. J. exp. Med., 135, 907

Levene, G. M., Wright, D. J. M., and Turk, J. L. (1971). Cell-mediated immunity and lymphocyte transformation in syphilis. Proc. roy. Soc. Med., 64, 426.

Lindahl-Kiessling, K., Alm, G., and Hanna, M. G., Jr., Eds. (1971). Morphological and functional aspects of immunity. Advanc. exp. Med. Biol., 12

Miller, J. F. A. P. (1961). Immunological function of the thymus. Lancet, 2, 748.

Miller, J. F. A. P., and Mitchell, G. F. (1968). Cell to cell interaction in the immune response. I. Hemolysin-forming cells in neonatally thymectomized mice reconstituted with thymus or thoracic duct lymphocytes. J. exp. Med., 128, 801 .

Morris, B. (1968). Migration intratissulaire des lymphocytes du mouton. Nouv. Rev. franc. Hemat., 8, 525, and General Discussion, 745.

Parrott, D. M. V., de Sousa, M. A. B., and East, J. (1966). Thymusdependent areas in the lymphoid organs of neonatally thymectomized mice. J. exp. Med., 123, 191.

Parrott, D. M. V., and de Sousa, M. A. B. (1971). Thymus-dependent and thymus-independent populations: origin, migratory patterns and life span. Clin. exp. Immunol., 8, 663.

Ruchti, C., Cottier, H., Cronkite, E. P., Jansen, C. R., and Rai, K. R. (1970). Studies on lymphocytes. XVII. Differential lymphocyte depletion in lymphoreticular organs of the calf during continuous extracorporeal x-irradiation of the circulating blood. Cell Tissue Kinet., 3, 301.

Sordat, B., Sordat, M., Hess, M. W., Stoner, R. D., and Cottier, H. (1970). Specific antibody within lymphoid germinal center cells of mice after primary immunization with horseradish peroxidase: a light and electron microscopic study. J. exp. Med., 131. 77.

Sordat, B., Hess, M. W., and Cottier, H. (1971). IgG immunoglobulin in the wall of post-capillary venules: possible relationship to lymphocyte recirculation. Immunology, 20, 115.

Turk, J. L., and Bryceson, A. D. M. (1971). Immunological phenomena in leprosy and related diseases. Advanc. Immunol., 13. 209.

Turk, J. L., and Waters, M. F. R. (1971). Immunological significance of changes in lymph nodes across the leprosy spectrum. Clin. exp. Immunol., 8, 363.

Turk, J. L., and Oort, J. (1970). The production of sensitized cells in cell-mediated immunity. In Handbuch der allgemeinen Pathologie (edited by H. Cottier and A. Studer, Vol. 7, pt. 3, p. 392. Springer, Berlin and New York).

Turk, J. L. (1971). Granuloma formation in lymph nodes. Proc. roy. Soc. Med., 64, 942.

Tyan, M. L., and Herzenberg, L. A. (1968). Studies on the ontogeny of the mouse immune system. J. Immunol., 101, 446.

Waksman, B. H., Arnason, B. G., and Jankovic, B. D. (1962). Role of the thymus in immune reactions in rats. III. Changes in the lymphoid organs of thymectomized rats. J. exp. Med., 116, 187. 
Appendix I

Summary of Morphological Signs of Immunological

Status as Judged from Lymph Node Areas with

Intact Architecture

\begin{tabular}{|l|l|l|}
\hline & \\
\hline Presumed potential overall immune capacity \\
overall lymphocyte content \\
Presumed potential antibody producing capacity \\
lymphocyte content in cortical area \\
lymphocyte follicles \\
$\begin{array}{l}\text { Presumed potential cellular immune responsivenes s } \\
\text { lymphoryte content in paracortical area } \\
\text { Signs of active humoral antibody response } \\
\text { germinal centres } \\
\text { relative number } \\
\text { relative size } \\
\text { relative content in large lymphoid cells } \\
\text { relative number of mitotic figures } \\
\text { relative number of tingible body macrophages } \\
\text { medullary cords } \\
\text { content in large lymphoid cells } \\
\text { content in plasma cells } \\
\text { relative number of mitotic figures }\end{array}$ \\
$\begin{array}{l}\text { Signs of active cellular immune response } \\
\text { paracortical area } \\
\text { relative size } \\
\text { relative content in lymphocytes } \\
\text { relative number of mitotic figures } \\
\text { relative number of epithelioid cells }\end{array}$ & & \\
\hline
\end{tabular}

'Explanation of symbols: N, normal; 0, negative, none present; one, two or three plus or minus signs indicate slight, moderate, or marked deviation above or below the normal range.

The term 'normal range' relates to findings in lymph nodes of the same region and of healthy individuals in the same age and sex group. It is recommended that histiopathologists prepare a collection of 'normal' lymph nodes from different areas of the body and from patients of different ages, possibly also of different sexes, for comparison. These samples should be taken from cases dying suddenly without preceding illness.

C, cortex, GC, germinal centres; PC, paracortical area; M, medulla; Ex, tissue surrounding the lymph node. 


\section{Expanded Protocol for Reporting Lymph Node} Histology

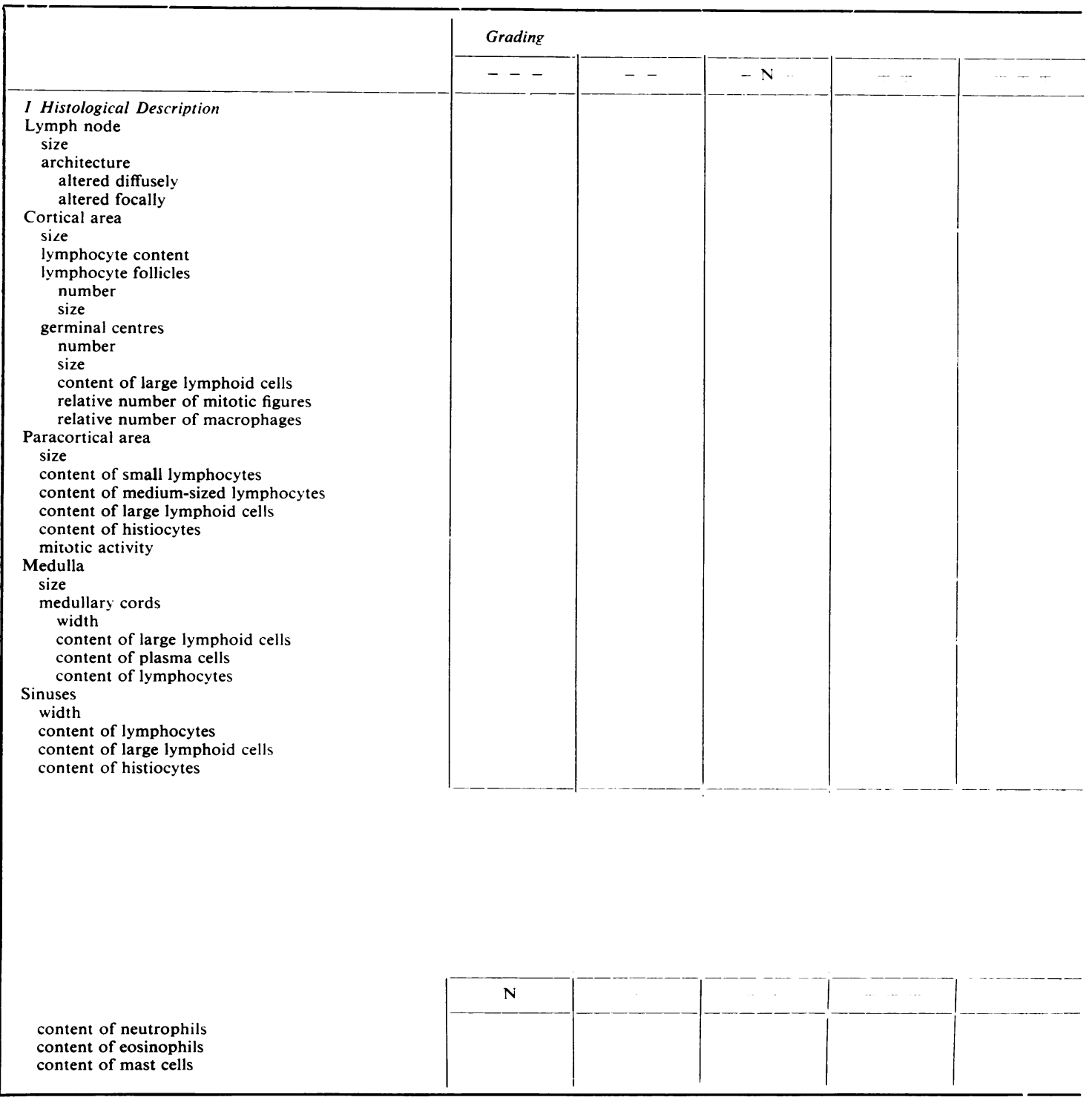

${ }^{1}$ Explanation of symbols: $\mathrm{N}$, normal; 0 , negative, none present; one, two or three plus or minus signs indicate slight, moderate, or marked deviation above or below the normal range.

The term 'normal range' relates to findings in lymph nodes of the same region and of healthy individuals in the same age and sex groups. It is 
Protocol for Reporting Lymph Node

Histology-continued

\begin{tabular}{|c|c|c|c|c|c|}
\hline & \multicolumn{5}{|c|}{ Localization $(+,++,+++)$} \\
\hline & $C$ & $G C$ & $P C$ & $\boldsymbol{M}$ & $E x$ \\
\hline $\begin{array}{l}\text { I Histological Description (continued) } \\
\text { Infiltrates of } \\
\text { neutrophils } \\
\text { eosinophils } \\
\text { histiocytes-macrophages } \\
\text { epithelioid cells } \\
\text { multinuclear giant cells } \\
\text { mast cells } \\
\text { others (specify) } \\
\text { Granulomas } \\
\text { histiocytic } \\
\text { epithelioid, small } \\
\text { epithelioid, tubercle } \\
\text { fibroblastic } \\
\text { central necrosis } \\
\text { central abscess } \\
\text { other (specify) } \\
\text { Necrosis } \\
\text { caseous } \\
\text { fibrinoid } \\
\text { other (specify) } \\
\text { Abscess } \\
\text { without granulomatous reaction } \\
\text { with granulomatous reaction } \\
\text { with epithelioid reaction } \\
\text { Fibrosis patchy } \\
\text { diffuse } \\
\text { Calcification } \\
\text { Pigment brown } \\
\text { haemosiderin } \\
\text { melanin } \\
\text { anthracotic } \\
\text { others } \\
\text { Silica } \\
\text { Foreign bodies } \\
\text { Lipid, intracellular (excluding fat cells) } \\
\text { Lipomatosis }\end{array}$ & & & & & \\
\hline
\end{tabular}

II Diugnosis or comments

\begin{tabular}{|c|c|c|c|c|}
\hline & 0 & + & $-\div$ & +++ \\
\hline $\begin{array}{l}\text { III Summary of morphological signs of immunological } \\
\text { status } \\
\text { Humoral antibody production } \\
\text { Cell-mediated immunity } \\
\text { Macrophage activity } \\
\text { Acute inflammation } \\
\text { Chronic inflammation }\end{array}$ & & & & \\
\hline
\end{tabular}

recommended that histiopathologists prepare a collection of 'normal' lymph nodes from different areas of the body and from patients of differen $t$ ages, possibly also of different sexes, for comparison. These samples should be taken from cases dying suddenly without preceding illness.

C, cortex, GC, germinal centres; PC, paracortical area; M, medulla; Ex, tissue surrounding the lymph node. 